\title{
PENGARUH KINERJA KEUANGAN PERUSAHAAN TERHADAP RETURN SAHAM PADA PERUSAHAAN MANUFAKTUR YANG TERDAFTAR DI BURSA EFEK INDONESIA TAHUN 2016-2018
}

Ni Luh Putu Swasti Gayatri ${ }^{1}$, Ni Made Sunarsih ${ }^{2}$

Universitas Mahasaraswati Denpasar

swastigayatri@gmail.com

\section{Paulus}

Journal of Accounting

ฮ

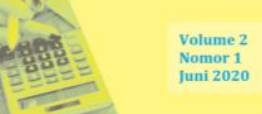

e-ISSN 2715-7474

p-ISSN 2715-9892

Informasi Artikel

Tanggal masuk

21 April 2020

Tanggal revisi

14 Mei 2020

Tanggal diterima

20 Juni 2020

\begin{abstract}
Abstrak: Return merupakan hasil yang diperoleh dari suatu investasi. Return saham dipengaruhi oleh berbagai faktor diantaranya rasio likuiditas, leverage, profitabilitas, dan aktivitas. Penelitian ini bertujuan untuk mengetahui pengaruh rasio likuiditas, leverage, profitabilitas, dan aktivitas terhadap return saham. Sampel dalam penelitian ini sejumlah 97 perusahaan manufaktur yang terdaftar di Bursa Efek Indonesia, yang terdiri dari 291 amatan. Metode penentuan sampel pada penelitian ini menggunakan purposive sampling. Data yang digunakan berupa data sekunder. Teknik analisis data yang digunakan dalam penelitian ini adalah regresi linier berganda. Hasil analisis menunjukkan bahwa rasio profitabilitas berpengaruh positif terhadap return saham, sedangkan rasio likuiditas, leverage dan aktivitas berpengaruh negatif terhadap return saham pada perusahaan manufaktur yang terdaftar di Bursa Efek Indonesia tahun 2016-2018.
\end{abstract}

Kata Kunci:

Likuiditas $^{1}$

Leverage $^{2}$

Profitabilitas $^{3}$

Aktivitas $^{4}$

Return Saham 5

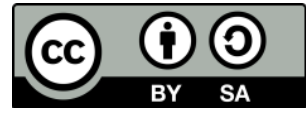

\section{PENDAHULUAN}

Di era ekonomi modern seperti sekarang ini, perusahaan sangat membutuhkan tambahan modal untuk mendorong kinerja operasional perusahaan. Salah satu cara bagi perusahaan untuk mendapatkan tambahan modal adalah dengan menawarkan kepemilikan perusahaan tersebut kepada masyarakat/publik (go public). Perkembangan Bursa Efek Indonesia yang sangat pesat saat ini tidak dapat dipisahkan dari peran investor yang melakukan transaksi dari Bursa Efek Indonesia (Kusumo, 2011).

Salah satu sub sektor yang menarik untuk diteliti adalah sektor industri manufaktur karena perusahaan manufaktur yang terdaftar di Bursa Efek Indonesia terdiri dari berbagai sub sektor industri dan memiliki jumlah emiten terbesar sehingga dapat mencerminkan reaksi pasar modal secara keseluruhan dan perusahaan manufaktur merupakan perusahaan yang memiliki produksi yang berkesinambungan sehingga memerlukan pengelolaan modal dan aktiva yang baik sehingga menghasikan profit yang 
besar untuk memberikan pengembalian investasi yang besar pula bagi para investor (Sembiring,2012).

Informasi yang berhubungan dengan kondisi perusahaan umumnya ditunjukkan dalam laporan keuangan yang merupakan salah satu ukuran kinerja perusahaan. Berdasarkan laporan keuangan tersebut, investor dapat memberikan penilaian kepada kinerja keuangan perusahaan terutama dalam pengambilan keputusan untuk melakukan investasi. Bagi para pemilik atau pemegang saham, laporan keuangan berfungsi untuk melihat tingkat pengembalian yang tercermin dalam laporan laba rugi dan besarnya dividen yang menjadi hak para pemegang saham Bramantyo, 2013).

Dalam melakukan investasi sekuritas saham, investor akan memilih saham perusahaan mana yang akan memberikan tingkat pengembalian (return) tinggi. Semakin tinggi tingkat return yang disyaratkan maka semakin tinggi juga risiko yang dihadapi, sehingga diperlukan informasi-informasi yang akurat untuk meminimalkan risiko tersebut (Solechan, 2009). Salah satu informasi yang dibutuhkan investor adalah laporan keuangan yang dipublikasikan oleh perusahaan (Susilowati, 2011). Bagi investor, laporan keuangan tahunan merupakan sumber berbagai macam informasi khususnya neraca dan laporan laba rugi perusahaan.

Kinerja keuangan perusahaan menggambarkan kondisi keuangan dan perkembangan perusahaan dalam mencapai tujuan perusahaan. Kinerja keuangan perusahaan menggambarkan tentang kondisi keuangan suatu perusahaan. Hal ini menunjukkan bahwa kinerja keuangan merupakan indikator yang dibutuhkan oleh pihak manajemen perusahaan untuk mengukur efektivitas kinerja perusahaan. Selain itu kinerja keuangan merupakan indikator yang digunakan investor sebelum melakukan investasi. Penilaian terhadap kinerja suatu perusahaan dapat dilakukan dengan menganalisis rasio keuangan perusahaan. Rasio-rasio yang digunakan dalam penelitian ini meliputi rasio likuiditas, rasio leverage, rasio profitabilitas dan rasio aktivitas.

Rasio likuiditas adalah rasio yang menggambarkan kemampuan perusahaan dalam memenuhi kewajiban (utang) jangka pendek (Kasmir, 2017:129). Penelitian ini menggunakan current ratio (CR) sebagai alat ukur dari rasio likuiditas untuk mengukur kemampuan perusahaan dalam membayar kewajiban jangka pendeknya dengan menggunakan aktiva lancar perusahaan (Hanafi dan Halim, 2014:77). Beberapa bukti empiris mengenai pengaruh current ratio (CR) terhadap return saham menunjukkan hasil yang berbeda-beda. Menurut Budialim (2013) dan Dewi (2016), current ratio (CR) memiliki pengaruh yang positif dan signifikan terhadap nilai return saham. Penelitian yang berbeda dilakukan oleh Bramantyo (2013) dan Rakasunsendra (2011) yang menjelaskan bahwa current ratio (CR) tidak berpengaruh secara signifikan terhadap return saham.

Rasio leverage merupakan rasio yang digunakan untuk mengukur sejauh mana aktiva perusahaan dibiayai dengan utang atau rasio yang digunakan untuk mengukur kemampuan perusahaan untuk membayar seluruh kewajibannya, baik jangka pendek maupun jangka panjang apabila perusahaan dibubarkan (dilikuidasi) (Kasmir, 2017:151). Untuk menghitung rasio solvabilitas dalam penelitian ini digunakan debt to 
equity ratio (DER), yaitu rasio yang digunakan untuk mengukur kemampuan perusahaan memenuhi hutang jangka panjangnya (Hanafi dan Halim, 2014:77). Beberapa bukti empiris mengenai pengaruh debt to equity ratio (DER) terhadap return saham menunjukkan hasil yang berbeda-beda. Menurut Dewi (2016) dan Sugiarto (2011) debt to equity ratio (DER) memiliki pengaruh yang negatif terhadap return saham. Penelitian yang berbeda dilakukan oleh Kusumo (2011) dan Arista (2012) menjelaskan bahwa rasio debt to equity ratio (DER) tidak berpengaruh secara signifikan terhadap return saham.

Rasio profitabilitas merupakan rasio untuk menilai kemampuan perusahaan untuk menghasilkan laba (Kasmir, 2017:196). Menjaga tingkat profitabilitas merupakan hal yang penting bagi perusahaan karena profitabilitas yang tinggi merupakan tujuan dari perusahaan. Jika dilihat dari perkembangan rasio profitabilitas menunjukkan suatu peningkatan hal tersebut menunjukkan kinerja perusahaan yang efisien (Martono, 2009). Untuk menghitung rasio profitabilitas dalam penelitian ini digunakan return on asset (ROA), yaitu raiso yang digunakan untuk mengukur kemampuan perusahaan didalam menghasilkan keuntungan dengan memanfaatkan aktiva yang dimilikinya karena dalam usahanya untuk memperoleh keuntungan perusahaan manufaktur cenderung menggunakan aset perusahaan dalam operasionalnya. Beberapa bukti empiris mengenai pengaruh return on asset (ROA) terhadap return saham menunjukkan hasil yang berbeda-beda. Menurut Mariani (2015) dan Arista (2012) return on asset (ROA) mempunyai pengaruh yang positif terhadap return saham suatu perusahaan. Penelitian yang berbeda dilakukan oleh Mende, dkk (2007), yang menyatakan bahwa profitabilitas tidak berpengaruh signifikan terhadap return saham.

Rasio aktivitas adalah rasio yang digunakan untuk mengukur efektivitas perusahaan dalam menggunakan aktiva yang dimilikinya (Kasmir,2017:172). Penelitian ini menggunakan inventory turnover (ITO) yaitu rasio yang digunakan untuk mengukur perputaran persediaan dalam satu periode (Karcaka and Savsar, 2012). Beberapa bukti empiris mengenai pengaruh inventory turnover (ITO) terhadap return saham menunjukkan hasil yang berbeda-beda. Menurut Karcaka and Savsar (2012) inventory turnover (ITO) mempunyai pengaruh yang positif terhadap return saham suatu perusahaan. Penelitian yang berbeda dilakukan oleh Firmansyah (2017), yang menyatakan bahwa rasio aktivitas tidak berpengaruh signifikan terhadap return saham.

Adanya inkonsistensi dalam penelitian tersebut menyebabkan munculnya research gap. Oleh karena itu perlu dilakukan penelitan yang lebih lanjut mengenai pengaruh current ratio (CR), debt to equity ratio (DER), return on asset (ROA), dan inventory turnover (ITO) terhadap return saham. Hal tersebut yang mendasari peneliti untuk melakukan penelitian kembali tentang Pengaruh Kinerja Keuangan Perusahaan terhadap Return Saham pada Perusahaan Manufaktur yang Terdaftar di Bursa Efek Indonesia tahun 2016-2018.

\section{METODE PENELITIAN}

\section{Lokasi Penelitian}


Penelitian ini dilakukan pada perusahaan Manufaktur yang terdaftar di Bursa Efek Indonesia tahun 2016-2018 dengan cara mengakses melalui alamat website www.idx.co.id.

\section{Identifikasi Variabel}

Penelitian ini menggunakan dua jenis variabel yaitu variabel independen atau variabel bebas dan variabel dependen atau variabel terikat dengan penjelasan sebagai berikut:

1) Variabel independen atau variabel bebas, yaitu variabel yang memengaruhi variabel terikat (Sugiyono, 2017:68). Variabel independen dalam penelitian ini adalah rasio likuiditas $\left(\mathrm{X}_{1}\right)$, rasio leverage $\left(\mathrm{X}_{2}\right)$, rasio profitabilitas $\left(\mathrm{X}_{3}\right)$, rasio aktivitas $\left(\mathrm{X}_{4}\right)$.

2) Variabel dependen atau variabel terikat, yaitu variabel yang dipengaruhi oleh variabel bebas (Sugiyono, 2017:68). Variabel terikat dalam penelitian ini adalah return saham (Y).

\section{Definisi Operasional Variabel}

1) Rasio Likuiditas (X1)

Likuiditas diproksikan dengan current ratio (CR) menunjukkan perbandingan nilai kekayaan lancar (yang segera dapat dijadikan uang) dengan hutang jangka pendek (Munawir, 2001). Menurut Husnan (2002), current ratio adalah rasio yang mengukur sejauh mana kemampuan aktiva lancar perusahaan biasa dipergunakan untuk memenuhi kewajiban lancarnya. Menurut Kasmir (2013:110), current ratio def(CR) dapat dirumuskan sebagai berikut :

$$
\text { Current Ratio }=\frac{\text { Aktiva Lancar }}{\text { Utang Lancar }}
$$

\section{2) Rasio Leverage (X2)}

Leverage ini diproksikan dengan debt to equity ratio (DER). DER yang tinggi menandakan modal usaha lebih banyak dibiayai oleh hutang dibandingkan dengan penggunaan modal sendiri. Menurut Kasmir (2013:151), debt to equity ratio (DER) dapat dirumuskan sebagai berikut :

$$
\text { Debt to Equity Ratio }=\frac{\text { Total Hutang }}{\text { Ekuitas }}
$$

3) Rasio Profitabilitas (X3)

Profitabilitas ini diproksikan dengan return on assets (ROA). ROA digunakan untuk mengukur efektifitas perusahaan didalam menghasilkan keuntungan (return) bagi perusahaan dengan memanfaatkan aktiva yang dimilikinya. Menurut Kasmir (2017:196), return on assets (ROA) dapat dirumuskan sebagai berikut :

Re turn On Asset $=\frac{\text { Laba Bersih }}{\text { Total Aktiva }}$

4) Rasio Aktivitas (X4)

Rasio aktivitas diproksikan dengan Inventory Turnover (ITO) yang bertujuan untuk mengukur sejauh mana efektivitas manajemen perusahaan dalam mengelola asset- 
asetnya, yaitu mengukur efisiensi pengelolaan persediaan yang memperlihatkan seberapa baiknya manejemen mengontrol modal yang ada. Menurut Kasmir (2017:172), Inventory Turnover (ITO) dapat dirumus sebagai berikut :

InventoryTurnover $=\frac{\mathrm{HPP}}{\text { Persediaan }}$

5) Return Saham (Y)

Hartono (2010:206) menjelaskan bahwa terdapat dua unsur pokok return total saham, yaitu capital gain (loss) dan yield. Return saham merupakan tingkat pengembalian investasi yang benar-benar diterima atau diperoleh investor akibat adanya perubahan harga saham dari waktu ke waktu. Menurut Jogiyanto (2010:2017), cara perhitungan return saham dapat dilakukan dengan rumus seperti berikut :

$$
R t=\frac{P_{t}-P_{t-1}}{P_{t-1}}
$$

\section{Jenis dan Sumber Data}

1) Jenis Data

Penelitian ini menggunakan jenis data kuantitatif, yaitu data yang berbentuk angka yang dapat dinyatakan dan diukur dengan satuan hitung (Sugiyono, 2017:23). Data kuantitatif dalam penelitian ini adalah laporan keuangan pada perusahaan Manufaktur yang terdaftar di Bursa Efek Indonesia (BEI) pada periode 2016-2018.

2) Sumber Data

Penelitian ini menggunakan sumber data sekunder, yaitu data yang telah diolah dan dipublikasikan oleh perusahaan atau pihak terkait yang dapat diperoleh secara tidak langsung yang biasanya berupa data dokumentasi arsip-arsip resmi (Sugiyono, 2017:456). Data sekunder dalam penelitian ini diperoleh dari situs resmi Bursa Efek Indonesia (BEI) berupa laporan keuangan perusahaan yang telah dipilih sebagai sampel.

\subsection{Metode Pengumpulan Data}

Penelitian ini menggunakan metode observasi non partisipan,yaitu metode pengumpulan data dengan melakukan pengamatan dan pencatatan terhadap data-data yang diperlukan pada perusahaan manufaktur yang terdaftar di BEI. Selain itu juga menggunakan metode dokumentasi pada penelitian ini metode dokumentasi berupa laporan keuangan tahunan perusahan manufaktur yang terdaftar di Bursa Efek Indonesia tahun 2016-2018.

Populasi dalam penelitian ini adalah seluruh perusahaan Manufaktur terdaftar di Bursa Efek Indonesia (BEI) tahun 2016-2018 yaitu sebanyak 166 perusahaan. Sampel adalah bagian dari jumlah dan karakteristik yang dimiliki oleh populasi tersebut (Sugiyono, 2017:137). Dalam penelitian ini pemilihan sampel dilakukan dengan menggunakan pendekatan non probability sampling yaitu dengan teknik purposive sampling, yang merupakan teknik penentuan sampel dengan pertimbangan atau kriteriakriteria tertentu (Sugiyono, 2017:144).

Adapun kriteria penentuan sampel dalam penelitian ini adalah sebagai berikut:

1) Seluruh Perusahaan Manufaktur yang terdaftar di Bursa Efek Indonesia selama tahun 2016-2018. 
2) Perusahaan Manufaktur yang mempublikasikan laporan keuangannya selama tahun 2016-2018.

3) Perusahaan Manufaktur yang menyajikan laporan keuangannya dalam bentuk mata uang rupiah selama tahun 2016-2018.

\subsection{Teknik Analisis Data}

\section{1) Statistik Deskriptif}

Statistik deskriptif adalah statistik yang digunakan untuk menganalisis data dengan cara mendeskripsikan atau menggambarkan data yang telah terkumpul sebagaimana adanya tanpa bermaksud membuat kesimpulan yang berlaku untuk umum atau generalisasi (Sugiyono, 2017:232). Statistik deskriptif digunakan untuk menggambarkan variabel-variabel yang digunakan dalam penelitian ini agar variabelvariabel tersebut dapat lebih jelas dan mudah dipahami.

\section{2) Uji Regresi Linear Berganda}

Menurut Ghozali (2016:91) analisis regresi pada dasarnya berkaitan dengan studi ketergantungan suatu variabel terikat (dependent) pada satu atau lebih variabel bebas atau penjelas (independent) dengan tujuan untuk mengetahui seberapa besar pengaruh variabel independen terhadap variabel dependen. Dalam penelitian ini, analisis regresi linear berganda digunakan untuk mengetahui signifikansi pengaruh rasio likuiditas, rasio leverage, rasio profitabilitas, dan rasio aktivitas terhadap return saham pada perusahaan Manufaktur yang listing di BEI. Model hubungan antara return saham dengan rasio likuiditas, rasio leverage, rasio profitabilitas, dan rasio aktivitas dapat disusun dalam persamaan linear sebagai berikut :

$$
\begin{aligned}
& \text { return saham }=\alpha+\beta_{1} \mathrm{CR}+\beta_{2} \\
& \mathrm{DER}+\beta_{3} \mathrm{ROA}+\beta_{4} \mathrm{ITO}+\mathrm{e}_{1} \ldots
\end{aligned}
$$

\section{3) Uji Asumsi Klasik}

Uji asumsi klasik digunakan untuk menguji apakah model yang dibuat apakah sudah valid serta menunjukkan hubungan yang signifikan dan representatif (Utama, 2012:99). Adapun uji asumsi klasik yang digunakan dalam penelitian ini adalah: 1. Uji Normalitas Menurut Ghozali(2016:154) uji normalitas ini bertujuan untuk menguji apakah dalam model regresi variabel terikat dan variabel bebas memiliki distribusi normal atau tidak. Model regresi yang baik adalah distribusi normal atau mendekati normal dasar pengambilan keputusan memenuhi normalitas atau tidak. 2. Uji Multikolinearitas Uji multikolinearitas bertujuan untuk menguji apakah model regresi ditemukan adanya korelasi antar variabel bebas (Ghozali, 2016:103). 3. Uji Heteroskedastisitas Menurut Ghozali (2016:134) uji heteroskedastisitas bertujuan untuk menguji apakah dalam model regresi linier terjadi ketidaksamaan varian dari residual satu pengamatan ke pengamatan yang lain. Jika varian dari residual satu pengamatan ke pengamatan lain tetap, maka disebut Homokedastisitas dan jika berbeda disebut heteroskedastisitas. 4. Uji Autokorelasi Uji autokorelasi bertujuan untuk menguji apakah dalam model regresi linear ada korelasi antara kesalahan pengganggu pada periode $\mathrm{t}$ dengan kesalahan pengganggu pada periode $\mathrm{t}-1$ sebelumnya. 
Autokorelasi muncul karena adanya observasi yang berurutan sepanjang waktu yang berkaitan satu sama lainnya. Masalah ini timbul karena residual tidak bebas dari satu observasi ke observasi lainnya (Ghozali, 2016:107).

\section{4) Uji Kelayakan Model}

Untuk menguji ketepatan fungsi model regresi sampel dalam menaksir nilai aktual dapat diukur dari goodness of fit. Uji kelayakan model goodness of fit dapat diukur melalui nilai determinasi $\mathrm{R}^{2}$, nilai statistik $\mathrm{F}$, dan nilai statistic t. 1. Koefisien Determinasi $\left(\mathbf{R}^{2}\right)$ Menurut Ghozali (2016:95), uji determinasi $\mathrm{R}^{2}$ mengukur seberapa jauh kemampuan model dalam menerangkan variasi variabel dependen. Nilai koefisien determinasi adalah antara nol dan satu $\left(0 \leq \mathrm{R}^{2} \leq 1\right)$. Nilai $\mathrm{R}^{2}$ yang kecil berarti kemampuan variable-variabel independen dalam menjelaskan variasi variabel dependen amat terbatas. 2. Uji F Dasar pengembilan keputusan yang digunakan uji F yaitu dengan membendingkan tingkat signifikansi 0,05 . Jika nilai probabilitas $\leq 0,05$, maka dapat dikatakan terdapat model Fit dengan data dan variabel independen secara serempak berpengaruh terhadap variabel dependen. Namun, jika nilai probabilitas $>0,05$ maka model tidak Fit dengan data (Ghozali, 2016:96). 3. Uji t Uji statistik t pada dasarnya menujukan seberapa jauh pengaruh satu variabel indepnden secara parsial dalam menerangkan variasi variabel dependen. Pengujian dilakukan dengan menggunakan signifikansi level 0,05 ( $\alpha=5 \%)$.

\section{HASIL DAN PEMBAHASAN}

\subsection{Statistik Deskriptif}

\begin{tabular}{|l|c|r|r|r|r|}
\hline & $\mathrm{N}$ & Minimum & \multicolumn{1}{c|}{ Maximum } & \multicolumn{1}{c|}{ Mean } & Std. Deviation \\
\hline CR & 291 & 2.140 & 831.820 & 219.05522 & 163.488556 \\
DER & 291 & -261.150 & $1,763.790$ & 7.38471 & 105.052976 \\
ROA & 291 & -54.850 & 71.600 & 4.30457 & 11.600115 \\
ITO & 291 & .560 & 107.010 & 5.54086 & 8.090841 \\
RETURN & 291 & -.750 & 26.860 & .30296 & 1.751484 \\
Valid N (listwise) & 291 & & & & \\
\hline
\end{tabular}

Berdasarkan Tabel diatas dapat dilihat bahwa jumlah data dalam pengamatan yaitu sebanyak 291 sampel. Penjelasan mengenai hasil perhitungan statistik diuraikan sebagai berikut : 1. Rasio Likuiditas diproksikan dengan Current Ratio (CR) memiliki nilai minimum sebesar 2,140 dan nilai maksimum sebesar 831,820 dengan nilai rata-rata (mean) sebesar 219,05522 dan standar deviasi 163,488556. 2. Rasio Leverage diproksikan dengan Debt to Equity Ratio (DER) memiliki nilai minimum sebesar -261,150 dan nilai maksimum 1.763,790 dengan nilai rata-rata (mean) sebesar 7,38471 dan standar deviasi 105,052976. 3. Rasio Profitabilitas diproksikan dengan Return on Asset (ROA) memiliki nilai minimum sebesar -54,850 dan nilai maksimum 71,600 dengan nilai rata-rata (mean) sebesar 4,30457 dan standar deviasi 11,600115. 4. Rasio Aktivitas diproksikan dengan Iventory Trun Over (ITO) memiliki nilai 
minimum sebesar 0,560 dan nilai maksimum 107,010 dengan nilai rata-rata (mean) sebesar 5,54086 dan standar deviasi 8,090841. 5. Rturn Saham memiliki nilai minimum sebesar -0,750 dan nilai maksimum 26,860 dengan nilai rata-rata (mean) sebesar 0,30296 dan standar deviasi 1,751484.

\subsection{Uji Asumsi Klasik}

1) Uji Normalitas

\begin{tabular}{|l|r|r|r|r|r|}
\hline \multirow{2}{*}{ Model } & \multicolumn{2}{|c|}{$\begin{array}{c}\text { Unstandardized } \\
\text { Coefficients }\end{array}$} & $\begin{array}{c}\text { Standardized } \\
\text { Coefficients }\end{array}$ & & \\
\cline { 2 - 4 } & \multicolumn{1}{c|}{ B } & Std. Error & \multicolumn{1}{|c|}{ Beta } & \multicolumn{1}{c|}{$\mathrm{t}$} & \multicolumn{1}{c|}{ Sig. } \\
\hline 1 (Constant) & .434 & .195 & & 2.225 & .027 \\
CR & -.001 & .001 & -.050 & -.797 & .026 \\
DER & .000 & .001 & -.021 & -.338 & .035 \\
ROA & .003 & .010 & .018 & .269 & .018 \\
ITO & -.004 & .013 & -.018 & -.310 & .047 \\
\hline
\end{tabular}

Hasil uji One Sampel Kolmogorov-Smirnov diperoleh nilai Asymp.Sig lebih besar dari 0,05 yaitu 0,990 maka dapat disimpulkan bahwa model persamaan regresi tersebut sudah berdistribusi secara normal.

\section{2) Uji Multikolinearitas}

Hasil uji multikolinearitas menunjukkan bahwa nilai Tolerance masing-masing variabel lebih dari 10 persen atau 0,1 dan nilai VIF kurang dari 10, sehingga dapat disimpulkan bahwa model regresi tidak terjadi multikolinearitas.

\section{3) Uji Autokorelasi}

\begin{tabular}{|l|c|r|r|r|r|}
\hline Model & \multicolumn{1}{|c|}{$\mathrm{R}$} & $\mathrm{R}$ Square & $\begin{array}{c}\text { Adjusted } \mathrm{R} \\
\text { Square }\end{array}$ & $\begin{array}{c}\text { Std. Error of the } \\
\text { Estimate }\end{array}$ & $\begin{array}{c}\text { Durbin- } \\
\text { Watson }\end{array}$ \\
\hline 1 & $.054^{4}$ & .073 & .811 & 0.761116 & 1.882 \\
\hline
\end{tabular}

Hasil uji autokorelasi menunjukkan bahwa nilai Durbin Watson sebesar 1,882. Nilai D-W menurut tabel dengan $\mathrm{n}=291$ dan $\mathrm{k}=4$ didapat nilai $\mathrm{dL}=1,779$ dan nilai $\mathrm{dU}=1,835$. Dari nilai tersebut adapun ketentuan yang dipenuhi adalah $\mathrm{du}<\mathrm{dw}<$ (4-du) yaitu $(1,779<1,882<2,221)$, yang artinya bahwa nilai DW sebesar 1,882 lebih besar dari 1,779 namun lebih kecil dari 2,221 sehingga dapat disimpulkan bahwa model regresi tidak terjadi autokorelasi.

\section{4) Uji Heteroskedastisitas}

\begin{tabular}{|l|r|r|r|r|r|}
\hline \multirow{2}{*}{ Model } & \multicolumn{2}{|c|}{$\begin{array}{c}\text { Unstandardized } \\
\text { Coefficients }\end{array}$} & $\begin{array}{c}\text { Standardized } \\
\text { Coefficients }\end{array}$ & & \\
\cline { 2 - 4 } & \multicolumn{1}{|c|}{ B } & Std. Error & \multicolumn{1}{c|}{ Beta } & \multicolumn{1}{c|}{$\mathrm{t}$} & \multicolumn{1}{c|}{ Sig. } \\
\hline 1 (Constant) & .745 & .185 & & 4.023 & .000 \\
CR & -.001 & .001 & -.071 & -1.140 & .255 \\
DER & .000 & .001 & -.031 & -.501 & .617 \\
ROA & -.004 & .009 & -.025 & -382 & .703 \\
ITO & -.007 & .012 & -.033 & -.558 & .577 \\
\hline
\end{tabular}

Menunjukkan bahwa semua variabel bebas memiliki nilai signifikansi yaitu : 0,255; 0,617; 0,703; dan 0,577 menunjukkan bahwa nilai signifikansinya > 0,05 maka dapat disimpulkan bahwa tidak terdapat gejala heteroskedastisitas.

\subsection{Analisis Regresi Linear Berganda}

\begin{tabular}{|l|r|r|r|r|r|}
\hline \multirow{2}{*}{ Model } & \multicolumn{2}{|c|}{$\begin{array}{c}\text { Unstandardized } \\
\text { Coefficients }\end{array}$} & $\begin{array}{c}\text { Standardized } \\
\text { Coefficients }\end{array}$ & & \\
\cline { 2 - 4 } & \multicolumn{1}{|c|}{ B } & Std. Error & \multicolumn{1}{c|}{ Beta } & \multicolumn{1}{c|}{$\mathrm{t}$} & \multicolumn{1}{c|}{ Sig. } \\
\hline 1 (Constant) & .434 & .195 & & 2.225 & .027 \\
CR & -.001 & .001 & -.050 & -.797 & .026 \\
DER & .000 & .001 & -.021 & -.338 & .035 \\
ROA & .003 & .010 & .018 & .269 & .018 \\
ITO & -.004 & .013 & -.018 & -.310 & .047 \\
\hline
\end{tabular}


Berdasarkan Tabel diatas dapat ditulis persamaan regresi linear berganda sebagai berikut :

Return Saham : 0,434 - 0,001CR + 0,000DER + 0,003ROA - 0,004ITO

\subsection{Uji Kelayakan Model}

\section{1) Uji Koefisien Determinasi}

\begin{tabular}{|l|l|r|r|r|r|}
\hline Model & \multicolumn{1}{|c|}{$\mathrm{R}$} & $\mathrm{R}$ Square & $\begin{array}{c}\text { Adjusted R } \\
\text { Square }\end{array}$ & $\begin{array}{r}\text { Std. Error of } \\
\text { the Estimate }\end{array}$ & $\begin{array}{c}\text { Durbin- } \\
\text { Watson }\end{array}$ \\
\hline 1 & $.054^{\mathrm{a}}$ & .073 & .811 & 0.761116 & 1.882 \\
\hline
\end{tabular}

Berdasarkan tabel diatas menunjukkan bahwa nilai adjusted $R$-Square adalah sebesar 0,811 yang berarti perubahan-perubahan yang terjadi terhadap return saham sebesar $81,1 \%$ disebabkan oleh rasio likuiditas (CR), rasio leverage (DER), rasio profitabilitas (ROA), dan rasio aktivitas (ITO) secara bersama-sama, sedangkan sisanya sebesar 18,9\% disebabkan oleh faktor lain seperti variabel-variabel lain diluar model yang sebenarnya turut mempengruhi return saham tetapi tidak dimasukan dalam model regresi.

\section{2) Uji F}

\begin{tabular}{|c|c|c|c|c|c|}
\hline Model & $\begin{array}{l}\text { Sum of } \\
\text { Squares }\end{array}$ & Df & $\begin{array}{l}\text { Mean } \\
\text { Square }\end{array}$ & F & Sig. \\
\hline 1 Regression & 2.595 & 4 & \multirow{3}{*}{$\begin{array}{r}649 \\
3.102\end{array}$} & \multirow{3}{*}{222.209} & \multirow[t]{3}{*}{.033} \\
\hline Residual & 887.037 & 286 & & & \\
\hline Total & 889.632 & 290 & & & \\
\hline
\end{tabular}

Berdasarkan tabel diatas diperoleh nilai $\mathrm{F}$ hitung sebesar 222,209 dengan tingkat signifikansi sebesar 0,033 . Hal tersebut menunjukkan model penelitian memiliki probabilitas signifikan lebih kecil dari 0,05, maka mengindikasikan bahwa variabel bebas yaitu rasio likuiditas (CR), rasio leverage (DER), rasio profitabilitas (ROA), dan rasio aktivitas (ITO) berpengaruh secara simultan terhadap return saham perusahaan.

\section{3) Uji Statistik t}

\begin{tabular}{|l|r|r|r|r|r|}
\hline \multirow{2}{*}{ Model } & \multicolumn{2}{|c|}{$\begin{array}{c}\text { Unstandardized } \\
\text { Coefficients }\end{array}$} & $\begin{array}{l}\text { Standardized } \\
\text { Coefficients }\end{array}$ & & \\
\cline { 2 - 4 } & \multicolumn{1}{|c|}{ B } & Std. Error & \multicolumn{1}{c|}{ Beta } & \multicolumn{1}{c|}{$\mathrm{t}$} & Sig. \\
\hline 1 (Constant) & .434 & .195 & & 2.225 & .027 \\
CR & -.001 & .001 & -.050 & -.797 & .026 \\
DER & .000 & .001 & -.021 & -.338 & .035 \\
ROA & .003 & .010 & .018 & .269 & .018 \\
ITO & -.004 & .013 & -.018 & -.310 & .047 \\
\hline
\end{tabular}

Berdasarkan tabel diatas pengaruh masing-masing variabel bebas terhadap variabel terikat dapat dijelaskan sebagai berikut :

1) Berdasarkan hasil uji t pada model regresi diperoleh nilai koefisien pada variabel rasio likuiditas (CR) sebesar $-0,001$, nilai t hitung sebesar $-0,797$, dengan nilai signifikansi sebesar 0,026 yang lebih kecil dari 0,05. Hal ini berarti bahwa CR berpengaruh negatif terhadap returm saham. Maka dapat disimpulkan $\mathrm{H}_{1}$ ditolak.

2) Berdasarkan hasil uji t pada model regresi diperoleh nilai koefisien pada variabel rasio leverage (DER) sebesar 0,000 , nilai t hitung sebesar $-0,338$, dengan nilai 
signifikansi sebesar 0,035 yang lebih kecil dari 0,05. Hal ini berarti bahwa DER berpengaruh positif terhadap returm saham. Maka dapat disimpulkan $\mathrm{H}_{2}$ ditolak.

3) Berdasarkan hasil uji t pada model regresi diperoleh nilai koefisien pada variabel rasio profitabilitas (ROA) sebesar 0,003, nilai t hitung sebesar 0,269, dengan nilai signifikansi sebesar 0,018 yang lebih kecil dari 0,05. Hal ini berarti bahwa ROA berpengaruh positif terhadap returm saham. Maka dapat disimpulkan $\mathrm{H}_{3}$ diterima.

4) Berdasarkan hasil uji t pada model regresi diperoleh nilai koefisien pada variabel rasio aktivitas (ITO) sebesar $-0,004$, nilai t hitung sebesar $-0,310$, dengan nilai signifikansi sebesar 0,047 yang lebih kecil dari 0,05. Hal ini berarti bahwa ITO berpengaruh negatif terhadap returm saham. Maka dapat disimpulkan $\mathrm{H}_{4}$ ditolak.

\section{Pengaruh Rasio Likuiditas terhadap Return Saham}

Hipotesis Pertama ditolak, Hal ini menunjukkan jika likuiditas perusahaan semakin tinggi maka return saham perusahaan akan semakin rendah yang disebabkan karena keuangan perusahaan terlalu didominasi oleh hutang jangka pendek dibandingkan dengan kas atau aset lancarnya, sedangkan perusahaan tidak mempunyai modal kerja yang cukup sehingga akan menimbulkan risiko bisnis yang tinggi bagi perusahaan. Tingkat likuiditas yang tinggi terhadap kewajiban lancar akan mengakibatkan dana perusahaan berkurang sehingga perusahaan tidak dapat optimal dalam operasionalnya. Informasi tersebut akan direspon oleh pemegang saham atau investor yang berakibat akan dilepasnya saham yang dimiliki sehingga menurunkan harga saham dan berdampak pada berkurangnya return saham dari perusahaan tersebut.

Hasil penelitian ini sejalan dengan penelitian yang dilakukan oleh Ganerse (2014) dan Raningsih (2015) yang menyatakan bahwa rasio likuiditas berpengaruh negatif terhadap return saham.

\section{Pengaruh Rasio Leverage terhadap Return Saham}

Hipotesis kedua ditolak, Hal ini menunjukkan jika leverage perusahaan semakin tinggi maka return saham perusahaan akan semakin tinggi, perusahaan yang mampu memanfaatkan dana asing atau hutang dengan maksimal akan mempunyai kesempatan lebih besar untuk melakukan ekspansi atau kegiatan operasional yang lebih luas sehingga keuntungan yang diperoleh dari pemanfaatan hutang tersebut akan lebih tinggi daripada bunga hutang yang dikenakan, sehingga apabila hutang digunakan dengan baik dan maksimal maka akan menghasilkan keuntungan atau return yang tinggi bagi perusahaan.

Hasil penelitian ini sejalan dengan penelitian yang dilakukan oleh Susilowati dan Turyanto (2011), Sutriani (2014) yang menyatakan bahwa rasio leverage berpengaruh positif terhadap return saham.

\section{Pengaruh rasio profitabilitas terhadap return saham}

Hipotesis ketiga diterima, Hal ini menunjukkan jika profitabilitas perusahaan meningkat maka return saham perusahaan juga akan meningkat yang disebebakn karena ROA menunjukkan kinerja perusahaan untuk menghasilkan laba bersih dari aktiva yang digunakan untuk operasional perusahaan. Meningkatkan ROA berarti di sisi lain 
meningkatkan pendapatan bersih perusahaan yangberarti nilai penjualan juga meningkat. Perusahaan yang memiliki nilai jual yang meningkat, akan mendorong terjadinya peningkatan laba yang menunjukkan kinerja keuangan perusahaan berada dalam keadaan baik. Hal ini menunjukkan jika perusahaan yang mampu menghasilkan laba atau keuntungan akan mempunyai kesempatan lebih besar untuk menghasilkan return saham karena perusahaan telah berkinerja dengan baik serta dapat meningkatkan harga sahamnya.

Hasil penelitian ini sejalan dengan penelitian yang dilakukan oleh Mariani (2015), dan Raningsih (2015) yang menyatakan bahwa rasio profitabilitas berpengaruh positif terhadap return saham.

\section{Pengaruh rasio aktivitas terhadap return saham}

Hipotesis keempat ditolak, Hal ini menunjukkan jika aktivitas perusahaan terlalu tinggi maka return saham perusahaan akan semakin rendah yang disebabkan karena semakin sering atau semakin tinggi perputaran persediaan maka akan semakin tinggi biaya yang dikeluarkan sehingga mengurangi jumlah laba yang diperoleh perusahaan yang menyebabkan turunnya minat investor untuk berinvestasi dan penurunan return saham.

Hasil penelitian ini sejalan dengan penelitian yang dilakukan oleh Setiyawan (2014) yang menyatakan bahwa rasio aktivitas berpengaruh negatif terhadap return saham.

\section{SIMPULAN}

Berdasarkan pembahasan hasil analisis data dan pembahasan hasil penelitian yang telah dilakukan, maka dapat disimpulkan sebagai berikut :

1) Rasio likuiditas berpengaruh negatif terhadap return saham pada perusahaan manufaktur yang terdaftar di Bursa Efek Indonesia.

2) Rasio leverage berpengaruh positif terhadap return saham pada perusahaan manufaktur yang terdaftar di Bursa Efek Indonesia.

3) Rasio profitabilitas berpengaruh positif terhadap return saham pada perusahaan manufaktur yang terdaftar di Bursa Efek Indonesia.

4) Rasio aktivitas berpengaruh negatif terhadap return saham pada perusahaan manufaktur yang terdaftar di Bursa Efek Indonesia.

\section{DAFTAR PUSTAKA}

Arista, Desy. 2012. Analisis Faktor-Faktor Yang Mempengaruhi Return Saham. Jurnal Ilmu Manajemen Dan Akuntansi Terapan, Vol. 3, No.1, Mei 2012.

Artini, I Dewa Ayu Made., Mahaputra, I Nyoman Kusuma Adnyana. 2014. "Analisis Pengaruh Komponen Arus Kas dan Laba Akuntansi terhadap Return Saham Perusahaan Manufaktur Jenis Consumer Goods Industry yang Terdaftar di BEI Periode 2011-2013". Jurnal Universitas Mahasaraswati, Vol. 4 Edsus Desember 2014. 
Bramantyo, Nugroho., dan Daljono. 2013. Pengaruh Kinerja Keuangan Terhadap Return Saham. Diponogoro Journal Of Accounting, Volume 2, Nomor 1, Tahun 2013, Halaman 1-11.

Brigham, Eugene F., and Houston, Joel F. 2011. Dasar-Dasar Manajemen Keuangan Perusahaan. Buku 2 Edisi 11. Jakarta : Selemba Empat.

Budialim, Giovanni. 2013. Pengaruh Kinerja Keuangan dan Risiko Terhadap Return Saham Sektor Consumer Goods di Bursa Efek Indonesia Periode 2007-2011. Jurnal Ilmiah, Mahasiswa Universitas Surabaya, Vol. 3, No. 1 (2013).

Chandra Desy Larashati, Ni Made. 2015. Pengaruh Kinerja Keuangan dan Income Smoothing terhadap Return Saham pada Perusahaan Sektor Industri Barang Konsumsi yang Terdaftar di Burs Efek Indonesia. Skripsi, Universitas Mahasaraswati Denpasar.

Dewi, Putu Eka Dianita Marvilianti. 2016. Pengaruh Rasio Likuidias, Profitabilitas, Solvabilitas, Aktivitas dan Penilian Pasar Terhadap Return Saham. Jurnal Ilmiah Akuntansi, Vol. 1, No. 2, Hal: 109-132.

Dwialesi, Junita Bias dan Darmayanti, Ni Putu Ayu. 2016. Pengaruh Faktor-Faktor Fudamental Terhadap Return Saham Indeks Kompas 100. E-Jurnal Manajemen Unud, Vol. 5, No. 4, Hal: 2544-2572.

Dwi Jayanti Putri Utami, Kadek. 2016. Pengaruh Rasio Keuangan, Inflasi dan Tingkat Suku Bunga pada Return Saham Perusahaan Manufaktur yang terdaftar di Bursa Efek Indonesia tahun 2012-2015. Skripsi, Universitas Mahasaraswati Denpasar.

Fahmi, Irham. 2011. Analisis Kinerja Keuangan, Panduan bagi Akademik, Manajer, dan Investor Untuk Menilai dan Menganalisis Bisnis dari Aspek Keuangan. Bandung : Alfabeta

Firmansyah. 2017. Pengaruh ITO, DER, ROA Terhadap Return Saham Pada Kompas 100 di BEI 2013-2015. Jurnal Program Studi Manajemen Sekolah Tinggi Ilmu Ekonomi (STIE), Mahaputra Riau, Volume 7, Nomor 02.

Ganerse, I Made Brian. 2014. Pengaruh Profitabilitas, likuiditas dan Ukuran Perusahaan Terhadap Return Saham Perusahaan. Jurnal Fakultas Ekonomi Universitas Udayana, h: 1620-1632.

Ghozali, Imam. 2016. Aplikasi Analisis Multivariete Dengan Program IBM SPSS 23. Edisi 8. Cetakan ke VIII. Semarang : Badan Penerbit Universitas Diponegoro

Gitman, Lawrence J dan Chad J. Zutter. 2012. Principles of Managerial Finance. Edisi 13, Global Edition : Pearson Eduaction Limited.

Halim, Abdul. 2005. Analisis Investasi. Edisi Kedua. Jakarta: Salemba Empat. Alfabeta. 
Hanafi, Mamduh M., dan Halim, Abdul. 2014. Analisis Laporan Keuangan. Edisi tujuh, UPP AMP YKPN, Yogyakarta.

Harahap, Sofyan Syarif. 2004. Analisis Kritis Atas Laporan Keuangan. Jakarta : PT Raja Grafindo Persada

Hardiningsih, Pancawati., L.Suryanto,A. Chairiri. 2007. Faktor Fundamental dan Risiko Ekonomi Terhadap Return Saham Pada Perusahaan di BEJ: Studi Kasus Basic Industry \& Chemical. Jurnal Bisnis dan Stategi Vol. 8.

Hery. 2015. Analisis kinerja manajemen. Jakarta : PT Grasindo.

Husnan, S. 2009. Dasar-dasar Teori Portofolio \& Analisis Sekuritas. Yogyakarta : UPP STIM YKPN.

Jogiyanto, Hartono. 2010. Teori Portofolio dan Analisis Investasi. Edisi Keenam, Yogyakarta: BPFE.

Karacaka S., dan Savsar A. 2012. The Effect of Between Financial Ratios on Firm Value: Evidence From Turkey. Journal of Applied Economics, Sciences. 7(12): 5663.

Kasmir. 2013. Analisis Laporan Keuangan. Rajawali Pers : Jakarta . 2017. Analisis Laporan Keuangan. Jakarta : RajaGrafindo Persada.

Kusumo, RM., dan Gian, Ismoyo. 2011. Analisis Pengaruh Rasio Keuangan Terhadap Return Saham Pada Perusahaan Non Bank LQ 45. Skripsi, Universitas Diponegoro Semarang

Mariani, Ni Luh Lina, dkk. 2016. Pengaruh Profitabilitas dan Leverage Terhadap Return Saham. Jurnal Manajemen, Vol. 4, No. 1, Universitas Pendidikan Ganesha.

Martono, Nugroho Cahyo. 2009. Pengaruh Faktor Fundamental Perusahaan dan Nilai Tukar terhadap Return Saham pada Perusahaan yang Terdaftar di BEI (Kasus pada Perusahaan Manufaktur Periode Tahun 2003 - 2007). Tesis, Program Pasca Sarjana Magister Manajemen Universitas Diponegoro, Semarang.

Marpaung, Elizabeth I., Hadianto, Bram. 2009. Pengaruh Profitabilitas dan Kesempatan Investasi terhadap Kebijakan Dividen: Studi Empirik pada Emiten Pembentuk Indeks LQ45 di Bursa Efek Indonesia. Jurnal Akuntansi, 1 (1), h: 70-84.

Mende, Stacy dan Van Rate, Paulina. 2017. Pengaruh Likuiditas, Solvabilitas dan Rentabilitas Terhadap Return Saham Perusahaan Sektor Properti dan Real Estate yang Tercatat di Bursa Efek Indonesia Periode 2012-2015. Jurnal EMBA, Vol. 5 No. 2, Hal: 2193-2202, Universitas Sam Ratulangi. 
Minar, Simanungkalit. 2009. Pengaruh Profitabilitas dan Rasio Leverage Keuangan Terhadap Return Saham pada Perusahaan Makanan dan Minuman Terbuka di Indonesia. Tesis, USU, Medan.

Munawir, S. 2012. Analisis Laporan Keuangan. Yogyakarta: Penerbit Liberty. Yogyakarta

Paleni, Herman. 2015. Analisis kinerja keuangan pada pdam tirta bukit sulap kota libuklinggau. Jurnal akutanika, 1(2):92-104.

Raharjo, Susilo. 2006. Analisa Pengaruh Kinerja Keuangan terhadap Return Saham. Skripsi, Universitas Islam Negeri Sunan Kalijaga, Yogyakarta.

Rakasurendra. 2011. Pengaruh Kinerja Keuangan terhadap Return Saham yang Dimoderasi Dividen Payout Ratio pada Perusahaan Manufaktur yang terdaftar di Bursa Efek Indonesia. Jurnal Akuntansi, Vol. 10(2), Hal: 520-537, Universitas Udayana.

Raningsih, Ni Kadek. 2015. Pengaruh Beberapa Rasio Keuangan dan Ukuran Perusahaan terhadap Return Saham pada Perusahaan food and beverages di Bursa Efek Indonesia Periode 2010-2013. Skripsi, Universitas Udayana Denpasar.

Sakti, Tutus Alun Asoka, 2010. Pengaruh Return On Asset dan Debt To Equity Ratio Terhadap Return Saham Pada Perusahaan yang Terdaftar di Bursa Efek Indonesia (Kasus Pada Sektor Manufaktur Periode Tahun 2003-2007). Jurnal Ilmu Manajemen dan Akuntansi Terapan, Vol. 1, No. 1, pp. 1-12.

Samsul, Mohamad. 2006. Pasar Modal \& Manajemen Portofolio. Jakarta : Erlangga

Sandy, Ahmad dan Asyik, Nur Fadjrih. 2013. Pengaruh Profitabilitas dan Likuiditas terhadap Kebijakan Dividen Kas pada Perusahaan Otomotif. Jurnal Ilmu dan RisetAkuntansi, 1 (1), h: 58-76.

Sembiring, Hermansyah. 2012. Analisis Pengaruh Karakteristik Perusahaan Terhadap Kelengkapan Pengungkapan dalam Laporan Tahunan Perusahaan Manufaktur yang Terdaftar di Bursa Efek Indonesia. Jurnal Mediasi, Vol. 4 No. 1 Juni 2012.

Setiyawan, I., \& Pardiman, P. 2014. Pengaruh Current Ratio, Inventory Turnover, Time Interest Earned dan Return on Equity Terhadap Harga Saham Pada Perusahaan Manufaktur Sektor Barang Konsumsi Yang Terdaftar di BEI Periode 20092012. Nominal, Barometer Riset Akuntansi dan Manajemen, 3(2).

Situmorang, Syafrizal Helmi dan Ginting, Paham. (2008). Analisis Data Penelitian. Cetakan Kedua. Medan: USU Press.

Soerinawati. 2013. Analisis Pengaruh Kinerja Keuangan Perusahaan Terhadap Return Saham Pada Sektor Perdagangan Besar dan Eceran di Bursa Efek Indonesia. Skripsi, Universitas Pasundan, Bandung. 
Solechan, Achmad. 2009. Pengaruh Earning, Manajemen Laba, IOS, Beta, Size dan Rasio Hutang terhadap Return Saham pada Perusahaan uang Go Public di BEI. Jurnal Ilmiah. Mahasiswa Universitas FEB Universitas Brawijaya 1(2): 1-13

Sugiyono. 2014. Metode Penelitian Pendidikan Pendekatan Kuantitatif, Kualitatif, dan $R \& D$. Bandung: Alfabeta.

. 2016. Metode Penelitian Kuantitatif Kualitatif dan $R$ \& D. Bandung: PT.

Alfabeta

Alfabeta, CV.

2017. Metode Penelitian Kuantitatif, Kualitatif, dan R\&D. Bandung:

Sugiarto, Agus. 2011. Analisis Pengaruh Beta, Size Perusahaan, DER dan PBV Ratio Terhadap Return Saham. Jurnal Dinamika Akuntansi, Vol. 3, No.1.

Susilowati, Yeye., dan Turyanto, Tri. 2011. Reaksi Signal Rasio Profitabilitas dan Rasio Solvabilitas Terhadap Return Saham Perusahaan. Jurnal Dinamika Keuangan dan Perbankan, Hal: 68 - 87, Vol. 3, No.1.

Sunardi, Harjono. 2010. Pengaruh Penilaian Kinerja dengan ROI dan EVA terhadap Return Saham Pada Perusahaan yang Tergabung dalam indeks LQ 45 di Bursa Efek Indonesia. Jurnal Akuntansi, Vol. 2, No. 1, Mei, hlm 70-92.

Sunarto. 2008. Peran Persistensi Laba Memoderasi Hubungan Antara Earnings Opacity dengan Biaya Ekuitas dan Aktivitas Volume Perdagangan (Studi Empiris pada Perusahaan Go Public di Indonesia selain Sektor Keuangan dan Properti). Disertasi, Program Doktor Ilmu Ekonomi. Universitas Diponegoro. Semarang

Susanti, Ukik Dwi. 2010. Pengaruh Kandungan Informasi Komponen Laporan Arus Kas, Laba Kotor, Earning Per Share dan Debt to Equity Ratio terhadap Return Saham Pada Perusahaan Real Estate and Property yang Terdaftar di BEI. Skripsi, Fakultas Ekonomi Universitas Sebelas Maret Surakarta.

Sutriani, A. 2014. Pengaruh profitabilitas, leverage, dan likuiditas terhadap return saham dengan nilai tukar sebagai variabel moderasi pada saham LQ-45. Journal of Business \& Banking (JBB), 4(1), 67-80.

Tandelilin, Eduardus. 2007. Analisis Investasi dan Manajemen Portofolio. Edisi 1. Yogyakarta : BPFE

Yogyakarta : Kanisius

Taswan. 2010. Manajemen Perbankan, Konsep, Teknik, dan Aplikasi. Edisi Kedua. Yogyakarta : UPP STIM YKPN. 
Utama, Suyana. 2012. Aplikasi Analisis Kuantitatif. Edisi keenam. Denpasar:Fakultas Ekonomi Universitas Udayana.

Weston, J. Fred and Brigham, Eugene. 2004. Dasar-dasar Manajemen Keuangan. Edisi ketujuh. Jakarta : Erlangga.

Wiagustini, Ni Luh Putu. 2010. Dasar-Dasar Manajemen Keuangan. Denpasar : Udayana University Press.

Widodo, S. 2007. Analisis pengaruh rasio aktivitas, Rasio Profitabilitas, dan Rasio Pasar, Terhadap Return Saham Syariah dalam Kelompok Jakarta Islamic Index (jii) Tahun 2003-2005. Doctoral dissertation Program Pasca Sarjana, Universitas Diponegoro.

Widyarini, F. 2006. Pengaruh Faktor Fundamental Terhadap Return Saham Perusahaan Miscellaneous Industries Yang Terdaftar Di Bursa Efek Jakarta Periode 20022003. Universitas Diponegoro, Semarang.

Wijanti, N. W. N., \& Sedana, I. P. 2013. Pengaruh Likuiditas, Efektivitas Aktiva Dan Ukuran Perusahaan Terhadap Kebijakan Dividen Dan Harga Saham. E-Jurnal Manajemen, Universitas Udayana.

www.idx.co.id 